\title{
Concentration of uranium levels in groundwater
}

\author{
${ }^{1}$ M. N. S. Babu; ${ }^{2}$ R. K. Somashekar; ${ }^{3}$ S. A. Kumar; ${ }^{4}$ K. Shivanna; ${ }^{5}$ V. Krishnamurthy; ${ }^{6}$ K. P. Eappen \\ ${ }^{1}$ Department of Science and Humanities, PES Institute of Technology, Bangalore, India \\ ${ }^{2}$ Department of Environmental Sciences, Bangalore University, Bangalore, India \\ ${ }^{3}$ Analytical Chemistry Division, Bhabha Atomic Research Center, Mumbai, India \\ ${ }^{4}$ Isotope Application Division, Bhabha Atomic Research Center, Mumbai, India \\ ${ }^{5}$ Department of Chemistry (Science and Humanities) PES Institute of Technology, Bangalore, India \\ ${ }^{6}$ Environmental Assessment Division, Bhabha Atomic Research Center, Mumbai, India \\ Received 14 August 2007; revised 21 September 2007; accepted 12 October 2007; $\quad$ available online 10 March 2008
}

\begin{abstract}
The uranium isotopes during their course of their disintegration decay into other radioactive elements and eventually decay into stable lead isotopes. The cause of environmental concern is the emanation of beta and gamma radiation during disintegration. The present study tends to estimate uranium in groundwater trapped in granite and gneiss rocks. Besides, the study aims at estimating the radiation during natural disintegration process. The water samples were collected and analyzed following inductively coupled plasma mass spectrometric technique while water sample collection was given to the regions of Kolar District, South India, due to the representation. The significant finding was the observation of very high levels of uranium in groundwater compared to similar assays reported at other nearby districts. Also, the levels were considerable to those compared to groundwater levels of uranium reported by other scientists. On the basis of this study, it was inferred that the origin of uranium was from granite strata and there was a trend of diffusion observed in the course of flow-path of water in the region.
\end{abstract}

Key words: Water analysis, granite-gneiss, underground, flow-path, isotope

\section{INTRODUCTION}

The Uranium concentration in groundwater depends on lithology, geomorphology and other geological conditions of the region. In groundwater uranium is present both in dissolved and particulate form due to minerals such as Uranitie, Pitchblende and Cornalite or as secondary mineral in the form of complex oxides of silicates phosphates, vanadates, lignite and monazite sands (Mahesh 2001) or as secondary minerals in the form of complex oxides, silicates, phosphates, vanadates, lignite and monazite sands. Natural uranium bymass of isotope proportions are $99.275 \%$ for ${ }^{238} \mathrm{U}$, $0.72 \%$ for ${ }^{235} \mathrm{U}, 0.005 \%$ for ${ }^{234} \mathrm{U}$. Thus theoretically, the radioactivity of ${ }^{235} \mathrm{U}$ in water is negligible compared to ${ }^{238} \mathrm{U}$ (UNSCEAR, 1982). In the last few decades, the behavior of uranium and thorium decay series nuclides in groundwater has contributed to an understanding of the mechanisms of geochemical reactions and transport processes in rock water systems. However, many uncertainties persist regarding the behavior of these radio-elements in rock water systems, mainly due to the relative importance of nuclear alpha particle recoil and chemical processes, such as ion exchange, sorption and precipitation (Iyengar, 1990). Uranium is the heaviest naturally occurring elements and is found in an average concentration of $0.0003 \%(3 \mathrm{mg} / \mathrm{kg})$ in the earth crust. It is present at a concentration of about 3.0 $\mathrm{\mu g} / \mathrm{L}$ in seawater (Lal, 1968; CWC, 2000; Hess, 1985; Hakam, 2001; Bleise, 2003; Almeida, 2004; Guogang Jia, 2005). Uranium isotopes during their disintegration course decay into other radioactive elements and eventually decay to stable lead isotopes in the process emit beta and gamma radiation (Fontes, 1983). The decay products of ${ }^{238} \mathrm{U}\left({ }^{234} \mathrm{Th}\right.$ and $\left.{ }^{234} \mathrm{~Pa}\right)$ and ${ }^{234} \mathrm{U}\left({ }^{231} \mathrm{Th}\right)$ are responsible for the presence of beta and gamma radiations in purified natural uranium (Bleise, 2003). Uranium isotopes and their specific activity $(\mathrm{Bq} / \mathrm{g})$ are represented in Table 2 (UNSCEAR, 1982). ${ }^{238} \mathrm{U}$ has a half life of $4.47 \times 10^{9}$ years and its specific activity is $12,455 \mathrm{~Bq} /$ 
g. The study had dual objectives of estimating uranium as a natural radioactive element in groundwater samples by adopting advanced instrumental techniques as well as delineated the concentration of uranium distributed in the groundwater of Kolar district reflecting the abundance, flow-path through the groundwater current in the region.

\section{MATERIALS AND METHODS}

The Kolar district is characterized by the rocks of various geological formations of the Archaean and quaternary periods. The district is rich in mineral deposits like gold, graphite, ochre and kaolin. Three categories of rock, namely granites, gneisses and schists, occur in the region. Granites occupy a major portion of the district. Alluvium is distributed along the stream and river courses. Basic dyke intrude the above formations in some places. They predominantly occur in South-East, South-West and central sections in the district.

Study area: Kolar district falls in the plain regions and is located in the easternmost district of Karnataka, South India. It is situated between $12^{\circ} 46^{1}$ and $13^{\circ} 58^{1}$ North latitude and $77^{\circ} 21^{1}$ and $78^{\circ} 35^{1}$ East longitudes. The topography of the district is from undulating to plain land with a number of scattered hill rocks. The central and eastern parts of the district forming the valley of Palar basin are undulating and well cultivated. The average height of the land is $850 \mathrm{MSL}$. The district can be divided into three river basins, namely Palar, North Pennar and South Pinakini, taking birth in the southwestern part of the district and draining at different parts. The total population of the district is 25.36 lakhs and the population density is $30.7 / \mathrm{km}$ (District Statistics Report, 2005). A total of 52 groundwater samples were collected from bore-wells from all the taluks spread over the entire district of Kolar. Groundwater Sample was collected in a $100 \mathrm{~mL}$ plastic bottle with cap of inner seal type. The water samples were filtered using Whatman filter paper discs before the acidification to $\mathrm{pH}$ around 2 using nitric acids. The samples are then labeled, denoting all the details of time, place and date of sample collection. The samples were transported to laboratory and stored at room temperature to be taken up for uranium analysis later. The concentrations of natural uranium present in the groundwater samples were analyzed by ICPMS (Model VG PQ of M/s. Excel) via the standard run and with the respective reference uranium standards of 5 ppm, 50 ppm, 100 ppm etc. (APHA. 1995). The results are recorded in ppm and ppb levels.

\section{RESULTS AND DISCUSSION}

The groundwater uranium concentration range spanned between 0.3 to $1442.9 \mu \mathrm{g} / \mathrm{L}$. It is relevant to indicate that the World Health Organization prescribes $30 \mathrm{ppb}$ as a standard for uranium in drinking water. Computing to this prescribed level, $21.8 \%$ samples exceeded the permissible limits. The Uranium concentration in the drinking water samples of Chikmangalore area, Karnataka, has been reported to vary from 0.2 to $27.9 \mu \mathrm{g} / \mathrm{L}$ (ppb) (Manjunath, 2002). The reported concentration in China is $0.04-5.1 \mu \mathrm{g} / \mathrm{L}$ (Paziguiang et al., 1988) and 0.9-9.9 $\mu \mathrm{g} / \mathrm{L}$ (Padam Singh et al., 1995). The present study shows no agreement with these earlier studies on uranium and is very much on a higher side. Besides, there is a considerable radioactivity in other conventional minerals of commercial importance such as phosphate minerals, appetite, copper, gold lignite, bauxite and such other ores due to the presence of uranium. Mining and processing of these minerals can enhance the radium levels in the environment well above the normal background levels. Exposure to higher levels of uranium is of serious concern for public health (Orloff, 2004) due to its hazardous nature associated with internal exposure (Lawrie, 2000). Uranium concentrations in the water depend on some factors such as uranium content in the host aquifer rock and its chemical constituents, presence of oxygen and its complexion agents, chemical reactions with ions in solution and nature of the contact between Uraniferrous minerals and water (Hess, 1985). The mean levels or uranium distribution in the different taluks of the region is presented in Table 1. The distribution of uranium estimated from water samples collected in different regions does show a trend. Out of a total number of eleven taluks of the Kolar district, maximal concentration found in Chikballapur taluk indicating the presence of uranium due to the rock formation. An interesting finding is that the uranium concentration is higher in samples originating northern regions compared to that from the southern regions of the district. The taluks like Malur and Bangarpet located in the southern regions showed relatively lesser concentration of uranium distributed in the groundwater. It can be inferred from this fact that there is a decreasing trend in the uranium 
Int. J. Environ. Sci. Tech., 5 (2), 263-266, Spring 2008

Table 1: Mean ${ }^{238} \mathrm{U}$ levels according to taluks in Kolar District

\begin{tabular}{llll}
\hline No. & Taluks & $\begin{array}{c}\text { No. of } \\
\text { samples } \\
\text { (n) }\end{array}$ & $\begin{array}{l}\text { Mean } \pm \text { S.D. } \mu \mathrm{g} / \mathrm{L}, \\
\text { (Min. }- \text { Max.) }\end{array}$ \\
\hline 1. & Chickballapur & 8 & 291.08, (2.44- \\
2. & Gauribidanur & 13 & $1443.0)$ \\
3. & Sidlaghatta & 6 & $5.08,(0.33-15.25)$ \\
4. & Bagapalli and & 3 & $6.08,(0.77-13.66)$ \\
5. & Gudibanda & 5 & $23.03,(1.94-90.0)$ \\
6. & Mulbagal & 5 & $4.85,(4.51-5.20)$ \\
7. & Bangarpet and Malur & 10 & $15.77,(0.69-54.69)$ \\
8. & Srinivasapura and & 5 & $33.35,(3.85-$ \\
& Chintamani & & $145.53)$ \\
\hline
\end{tabular}

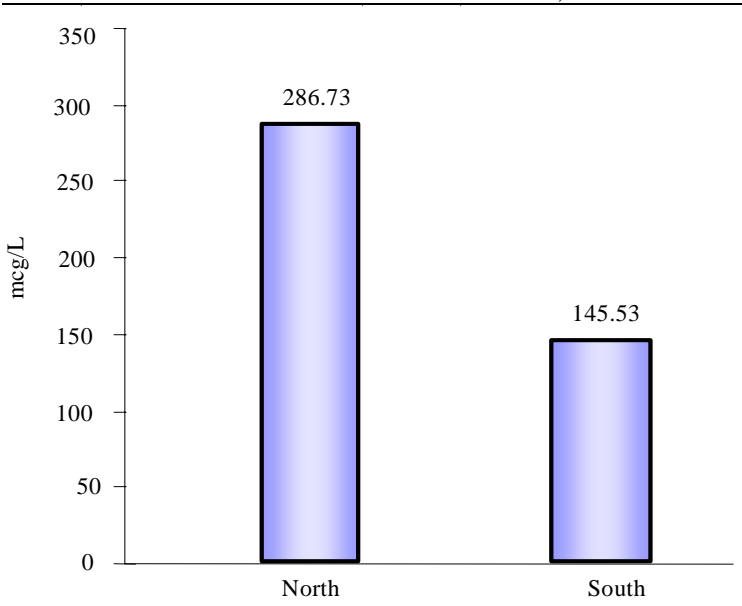

Fig. 1: Uranium levels in groundwater according to the north and south regions

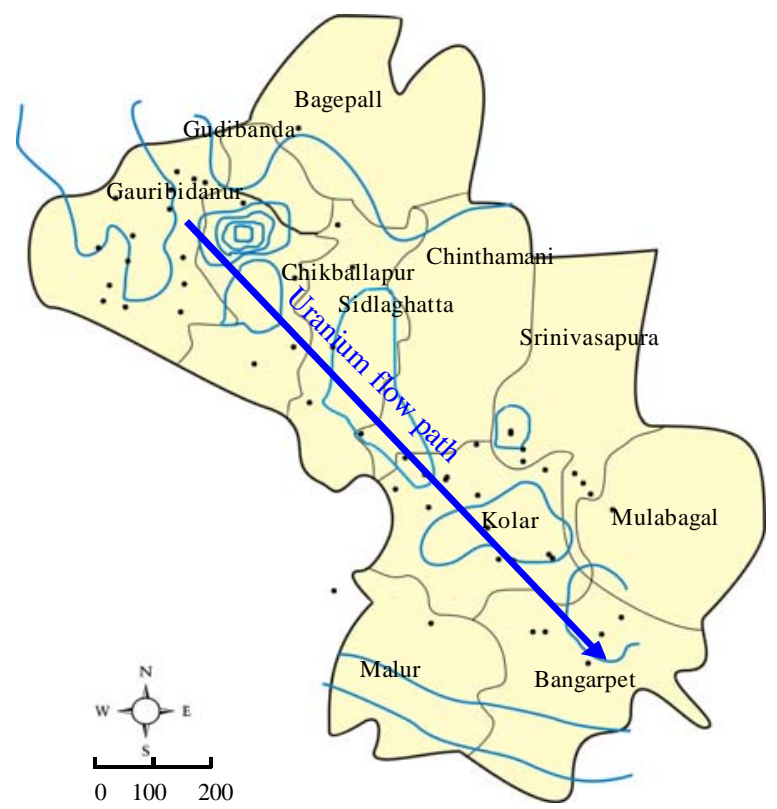

Fig. 2: Isoconcentric distribution of Uranium concentrations and spread pattern
Table 2: Characteristics of uranium isotopes in natural uranium

\begin{tabular}{llll}
\hline Isotope & Half life (years) & Relative (\%) & $\begin{array}{l}\text { Specific } \\
\text { activity }(\mathrm{Bq} / \mathrm{g})\end{array}$ \\
\hline${ }^{238} \mathrm{U}$ & $4.47 \times 10^{9}$ & 99.3 & 12,455 \\
${ }^{235} \mathrm{U}$ & $7.04 \times 10^{8}$ & 0.72 & 80,011 \\
${ }^{234} \mathrm{U}$ & $2.46 \times 10^{5}$ & 0.006 & $231 \times 10^{6}$ \\
\hline
\end{tabular}

concentrations along the groundwater flow. The Kolar district can be divided into two regions, namely northern and southern regions based on the levels or uranium levels in ground water observed in the present study. The northern comprises of taluks, namely Chickballapur, Gauribidanur, Sidlaghatta, Bagepalli and Gudibanda form the north region. The water samples were collected from the cusp-region of Bagepalli and Gudibanda and hence they are clubbed together for computing the mean levels. This region clearly shows an upward trend and distinctly appears to differ from the southern region of the district. The southern region comprises of Kolar, Mulbagal, Bangarpet, Malur, Srinivaspur and Chintamani taluks. Bangarpet with Malur and Srinivasapur with Chintamani are clubbed, since the collected water samples merged with each other in these regions. This finding urges to hypothecate that there is a certain flow path from northern to southern direction with respect to the uranium distribution in geological strata (Athavale, 1992). The recharge area is located in the north and the discharge area is in the south of the district. This indicates that there could be higher uranium concentrations in the granite rocks of the northern part which could be a source for ground water. Since groundwater flows from north to south, it exhibits a diffusion gradient running from the north to the south direction. The study revealed that the uranium is concentrated at some locations at Chikballapur taluk and gradually spread downwards as shown in Fig. 2.

\section{ACKNOWLEDGEMENT}

Grateful thanks to the board of research in Nuclear Sciences, Department of Atomic Energy, Government of India for extending financial support for the study.

\section{REFERENCES}

Almeida, R. M. R.; Lauria, D. C.; Ferreira, A. C.; Sracek, O., (2004). Groundwater radon, radium and uranium concentrations in Regiao dos Lagos, Rio de Janeiro State, Brazil. J. Environ. Radio., 73 (3), 323-334.

APHA (1995). Standard methods for the examination of water and wastewater, $19^{\text {th. }}$ Ed., Public health association, American water works Association and water environment fedration, USA. 9-1-9-63. 
Athavale, R. N.; Rangarajan, R.; Rao, S. M., (1992). Determination of the flow direction of geothermal water at Manikaran using the bore hole tracer technique. J. Geol. Soc. India. 39, 329-337.

Bleise, A.; Danesi, P. R.; Burkart, W., (2003). Properties use and health effects of depleted uranium (DU): A general overview. J. Environ. Radio., 64 (2-3), 93-112.

CWC (2000). Water and related statistics, Central Water Commission, Ministry of Water Resources, Govt. of India, New Delhi, India

Dillon, M. E.; Carter, G. L.; Arora, R., and Kahn, B., (1991). Radon concentrations in ground water of the Georgia piedmont., Health Physics., 60(2), 229-236.

District Report at a glance, District Statistical Department (2002-2005).

Fontes, J., (1983). Dating of groundwater, In: Guidebook of Nuclear techniques in Hydrology, Technical Report Series No. 91, International Atomic Energy Agency, Vienna, 285317.

Guogang Jia, Maria Belli, Umberto Sansone, Silvia Rosamilia and Stefania Gaudino. (2005). Concentration and characteristics of depleted uranium in water, air and biological samples collected in Serbia and Montenegro. Appl. Radiat. Isotopes, 63 (3), 381-399.

Hakam, O. K.; Choukri, A.; Moutia, Z.; Chouak, A.; Cherkaoui, R.; Reyss J. L.; Lferde, M., (2001). Uranium and radium in groundwater and surface water samples in Morocco, Radiat. Phys. Chem., 61 (3), 653-654.

Hess, C. T.; Michel, J.; Harton, T. R.; Procured, H. M.; Coniglio, W. A., (1985). The occurrences of radioactivity in public water supplies in United States., Health Phys., 48 (5), 55386.
Iyengar, M. A. R., (1990). The natural distribution of radium. The environmental behaviour of radium. Technical Reports Series No. 310, Int. Atomic Energy Agency, Vienna, 59128.

Lal, D.; Suess, H. E., (1968). The radioactive of the atmosphere and hydrosphere. Ann. Rev. Nuclear Sci., 18, 407-434.

Lawrie, W. C.; Desmond, J. A.; Spence, D.; Anderson, S.; Edmondson, C.; (2000). Determination of radium-226 in environmental and personal monitoring samples., Appl. Radiat.Isotopes, 53 (1), 133-137.

Mahesh, H. M.; Avadhani, D. N.; Someshekarappa, H. M.; Karunakara, N.; Narayana, Y., and Siddappa, K., (2001). Uranium concentration in water samples in the environment of coastal Karnataka and Kaiga. Proc. Nat. Sem. Atom. Energ. Ecol Environ., 113-116.

Manjunath, S., (2002). Ph.D. Thesis published by University of Mysore. Investigation of the Environmental radioactivity in uranium bearing quartz pebble conglomerate horizon around Chickmagalur., Department of Studies in Physics., Manasagangotri, University of Mysore.

Orloff, K. G.; Mistry, K.; Charp, P., (2004). Human exposure to uranium in groundwater. Environ. Res., 94 (3), 319-326.

Padam Singh, N. P. S.; Ameer A.; Naqvi, A. H.; Srivasan, D. S., (1995). Uranium contents in various water samples of Kanpur as determined by fission track technique., Proc. of $14^{\text {th. }}$ National Symposium on Environment., 201-4.

Panziquiang, Y. Y.; Guo M., (1988). National radiation and radioacivity in china radiation. Protec. Dosimetry., 24(1/ 4), 29-8.

UNSCEAR., (1982). Ionizing Radiation: Sources and biological effects., UN Report., New York.

\section{AUTHOR (S) BIOSKETCHES}

Sridhar Babu, M. N., Senior Lecturer, Department of Science and Humanities, PES Institute of Technology 100 ft ring Road, BSK III Stage, Bangalore -560 085, India. Email: ecomitra@gmail.com

Somashekar, R. K., Professor, Department of Environmental Sciences, Bangalore University, Bangalore 560056, India. Email: rksmadhu@rediffmail.com

Kumar, S. A., Analytical Chemistry Division, Bhabha Atomic Research Centre, Mumbai -400085, India. Email: Sanjukta_k@rediffmail.com

Shivanna, K., Head water Resources Development Section, Isotope Application Division, Bhabha Atomic Research Centre, Mumbai -400 085, India. Email: kshiva@barc.gov.in

Krishnamurthy, V., Professor, Department of Science and Humanities, PES Institute of Technology, $100 \mathrm{ft}$ ring Road, BSK III Stage, Bangalore -560085, India. Email: profvkm55@yahoo.com

Eappen, K. P. , Environmental Assessment Division, Bhabha Atomic Research Centre, Mumbai -400085, India. Email: eappen@barc.gov.in

This article should be referenced as follows:

Sridhar Babu, M. N.; Somashekar, R. K.; Kumar, S. A.; Shivanna, K.; Krishnamurthy, V.; Eappen, K. P. , (2008). Concentration of uranium levels in groundwater. Int. J. Environ. Sci. Tech., 5 (2), 263-266. 